\title{
IAMJ
}

INTERNATIONAL

AYURVEDIC

MEDICAL JOURNAL

\section{A CONCEPTUAL REVIEW ON PURISA (STOOL) PARIKSHA}

\author{
Ramnarayan Patel $^{1}$, Aradhana Kande ${ }^{2}$
}

${ }^{1}$ P.G. Scholar, Lecturer, Department of Roga Nidana Evam Vikriti Vigyan, Shri N. P. A. Govt. Ayurved College, Raipur, Chhattisgarh, India

Corresponding Author: dr.ram90@gmail.com

\section{https://doi.org/10.46607/iamj1509062021}

(Published Online: June 2021)

Open Access

(C) International Ayurvedic Medical Journal, India 2021

Article Received: 28/05/2021 - Peer Reviewed: 09/06/2021 - Accepted for Publication: 10/06/2021

\section{(D) Check for updates}

\section{ABSTRACT}

In Ayurved; Astasthana pariksha is one of the important examinations to find the various causes behind diseases. In Ayurvedic text, different methods have been described for diagnosis of various aspect of disease, the Purisa pariksha (Stool examination) is one of them. Purisa pariksha is the main laboratory investigation tool which is necessary to diagnosis the disease described under samanya pariksha regarding the abnormalities in terms of color, odor, quality, consistency etc. In all ancient days, the identification of ama is used to be done by purisa pariksha only. This review article aims to focus on the importance of Purisa pariksha. This conceptual study is helpful in the management of various progressive chronic diseases.

Keywords: Astasthana pariksha, Mala pariksha, Purisa pariksha, Stool.

\section{INTRODUCTION}

Purisa pariksha is described under Astasthana pariksha by Acharya Yogaratnakar. ${ }^{1}$ Purisa pariksha plays very important role in diagnosis of the disease. Examination of purisa gives much information regarding the condition of the doshas, dhatus, ahara paka etc. both in health and diseased states. Hence, Ayurved advocates it as a diagnostic method generally in all diseases and especially in disorders of Annavaha and Purisavaha srotas. $^{2}$ 


\section{Aim \& Objectives}

1. To study the status of Agni in the body.

2. To study the symptoms of abnormal doshas.

3. Prognosis of diseases.

4. To study about many physiological and pathological states of the body.

\section{Characteristic Of Prakrta (Normal) Purisa}

Characteristics of normal purisa in terms of physical characteristics during health such as samhata (wellformed solid), peeta (yellow), durgandha (bad smelling), laghu (light in weight), natisnigdha (not very viscid), natyalpa-natibahu (neither very less nor abundant in quantity), sukha pravrtti (easy expulsion) with one to two vegas per day. ${ }^{3}$ Pramana (quantity) of Purisa has been described by Acharya Charaka as Sapta Anjali Pramana. These features are influenced by many factors such as deha prakrti, ahara, vihara, kala, satmya, vyadhi etc. ${ }^{4}$

Precautions and Handling of the Purisa (stool) samples

- Stool should be collected in clean, dry container with a tightly fitting lid and transported to the laboratory immediately.

- Stool should not be contaminated with urine, water, soil or menstrual blood.

- Warm stools are best for detecting ova and parasites. Do not refrigerate for ova and parasites.

- Patients should not receive oily laxatives, antidiarrheal medication, bismuth, antibiotics like tetracycline or antacids for 7 days before stool examination.

- The semi-formed \& solid stool should be examined within 60 minutes of collection.

- The liquid stool should be examined within the first 30 minutes.

- In the case of constipated cases, use non-residual purgative on the night before the collection of the stool.

- For occult blood stop iron-containing drugs, meat and fish at least 48 hours before the collection.

- Multiple samples are needed to rule out the parasitic infestation.

- In the case of infants, collect from the diaper.
- Trophozoites are most likely to be found in loose or watery stools or in stools containing blood or mucus, while cysts are likely to be found in formed stool.

Indications of Purisa pariksha (Stool examination)

- To evaluate the function and integrity of the GI tract.

- To rule out the presence of WBCs and RBCs.

- To find ova or parasites.

- To see the presence of fat for malabsorption syndrome.

- For screening of colon cancer.

- For asymptomatic ulceration of GI tract.

- Evaluate diseases in the presence of diarrhea and constipation.

- To evaluate the intestinal bleeding, infestation, inflammatory diseases etc.

\section{Methods to prepare the stool smears}

1. Saline Wet mount - for trophozoites, cysts of protozoa, ova/larvae of helminthes.

2. Iodine Wet mounts - for identification of protozoal cysts. ${ }^{5}$

\section{TYPES OF EXAMINATION}

Examination of the Purisa (feces) is carried out in two ways:

1. Physical Examination: It is to note the varna (color), swabhava (consistency), gandha (odor), pramana (quantity) and samyoga (admixture).

2. Microscopical Examination: To detect ama dravyas (undigested food particles), krimi bija (ova of worms) or krimis (worms), rakta anu (blood cells especially the red cells). Culture of the stools for detecting different kinds of bacteria is also in vogue in the present day when absolutely necessary. ${ }^{6}$

\section{Pariksha Krama (Methods Of Examination)}

A great detail regarding the changes in physical characteristics of purisa has been described under various diseases in Brihattrayi. Examination should be carried out by the physician himself. The following methods are ideal;

1. Darsana (Inspection) - carefully look for varna (color), doshanusara properties, sangati (con- 
sistency), presence of froth, samyoga (admixture), samsthans (shape) etc. [Table 1 - 4]

2. Sparsana (Touching) - even though unpleasant touching the material may be ideal to know its qualities like sheeta (cold), ushna (warmth), picchila (unctuousness) etc. [Table 5]

3. Ghrana (Olfaction) - normal, increase or decrease of its foul smell, appearance of unusual smells etc. should be found in many diseases. [Table 6]

4. Prasna pariksha (Interrogation) - for number of vegas, feeling before, during and after expulsion, pramana (quantity), food and food habits and associated symptoms such as pain etc. will be of great advantage. [Table 7,8]
5. Yukti pariksha - to determine pakwa-apakwa by putting a small portion of the material on water and nothing whether it floats or sinks. Floating is normal and is called pakwa condition while sinking is apakwa or sama condition which is abnormal. ${ }^{7,8}$

\section{Jala Nimajjana Pariksha (Hydrostatic Test)}

This is the only objective method which was used in ancient times to detect the presence of Ama in purisa. Amapakwa nirnaya is done by putting a mass of puri$s a$ into a vessel containing water. If floats on water, it is indicative of pakwa state which is normal; but if it sinks it is considered as ama state which is abnormal. ${ }^{9-}$ 11

Table 1: Properties of Purisa (Stool) vitiated by Dosha

\begin{tabular}{|l|l|l|}
\hline S. No. & Dosha & Properties \\
\hline 1. & Vata & Dry, hard, frothy, blackish, constipated \\
\hline 2. & Pitta & Yellowish, mixed with blood, very frequent evacuations, offensive \\
\hline 3. & Kapha & Pale, white and mucoid with undigested materials, odorless \\
\hline 4. & Sannipata & Black, loose, yellowish, constipated, whitish colored, offensive \\
\hline
\end{tabular}

Table 2: The Color/Appearance of Purisa (Stool) in various diseases

\begin{tabular}{|c|c|c|}
\hline S. No. & Types of Color & Diseases \\
\hline 1. & Krishna & Kshaya roga, Vataja Arsha, Vataja Gulma, Kumbha Kamala, Vata prakopa \\
\hline 2. & Aruna & Vataja Atisara, Samgrahani \\
\hline 3. & Shyava Aruna & $\begin{array}{l}\text { Vataja Udara roga, Vataja Arsha, Vataja Atisara, Vataja Gulma, Vataja } \\
\text { Jwara, Vataja Pandu, Vata prakopa }\end{array}$ \\
\hline 4. & Shukla & $\begin{array}{l}\text { Kaphaja Jwara, Kaphaja Pandu, Kaphaja Udara roga, Kaphaja Arsha, } \\
\text { Kaphaja Atisara, Jalodara, Sahaja Arsha }\end{array}$ \\
\hline 5. & Rakta & Raktapitta, Chidrodara, Pittaja Atisara, Pittaja Atisara \\
\hline 6. & Peeta & Ama dosha, Pittaja Jwara, Pittaja Murccha, Pittaja Swarabheda \\
\hline 7. & Harita & Halimaka \\
\hline 8. & Lohita & Pittaja Atisara \\
\hline 9. & Gunjaphala Varna & Shokaja Atisara \\
\hline 10. & Tilpishtanibham & Shakhashrita Kamala \\
\hline
\end{tabular}

Table 3: The Consistency of Purisa (Stool) in various diseases

\begin{tabular}{|l|l|l|}
\hline S. No. & Consistency & Diseases \\
\hline 1. & Sandra & Kaphaja Atisara, Sahaja Arsha \\
\hline 2. & Baddha & $\begin{array}{l}\text { Tikshnagni, Alasaka, Ajirna, Paramada, Baddha gudodara, Vatadusta stan- } \\
\text { yapana, Purisavritta vata, Pratyasthila, Sahaja Arsha, Vataja Atisara, Vata- } \\
\text { ja Visarpa, Vataja Jwara, Vataja Arsha, Vataja Parinamasula, Purisaja } \\
\text { krimi, Sannipata Jwara }\end{array}$ \\
\hline 3. & Drava & Mandagni, Pittaja Arsha, Vataja Grahani, Asadhya Atisara \\
\hline
\end{tabular}




\begin{tabular}{|l|l|l|}
\hline 4. & Bhinna & $\begin{array}{l}\text { Kshayaja Kasa, Kaphavritta apana vayu, Kaphaja Grahani, Pittaja Arsha, } \\
\text { Pittaja Murccha, Sandharanajanya Yakshma }\end{array}$ \\
\hline 5. & Sushka & Udavarta, Vataja Grahani, Sahaja Arsha \\
\hline 6. & Ghana & Samgrahani \\
\hline
\end{tabular}

Table 4: Presence of froth in Purisa (Stool) in various diseases

\begin{tabular}{|l|l|l|}
\hline S. No. & Types of Froth & Diseases \\
\hline 1. & Phenila & Vataja Arsha, Vataja Atisara, Vataja Grahani \\
\hline 2. & Varahsneha-mamsambusadrish & Sannipataja Atisara \\
\hline
\end{tabular}

Table 5: The Sparsha (touch) of Purisa (Stool) in various diseases

\begin{tabular}{|l|l|l|}
\hline S. No. & Type of Sparsha & Diseases \\
\hline 1. & Sheeta & Ajirna, Kaphaja Atisara \\
\hline 2. & Ushna & Pittaja Arsha \\
\hline 3. & Snigdha & Kaphaja Arsha, Kaphaja Atisara \\
\hline 4. & Ruksha & Vataja Jwara, Vataja Atisara \\
\hline $\mathbf{5 .}$ & Picchila & Samgrahani \\
\hline
\end{tabular}

Table 6: The Odor of Purisa (Stool) in various diseases

\begin{tabular}{|l|l|l|}
\hline S. No. & Types of Odor & Diseases \\
\hline $\mathbf{1 .}$ & Daurgandhya & $\begin{array}{l}\text { Ama purisa, Purisavaha Srotodushti, Vid vighata, Pittaja Pandu, Kaphaja } \\
\text { Atisara, Sannipataja Chardi }\end{array}$ \\
\hline 2. & Vistragandhi & Pittaja Arsha, Kaphaja Atisara \\
\hline $\mathbf{3 .}$ & Atidurgandhita & Pittaja Arsha, Pittaja Atisara \\
\hline $\mathbf{4 .}$ & Amagandhi & Amatisara \\
\hline $\mathbf{5 .}$ & Kunapagandhi & Chidrodara, Sahaja Arsha \\
\hline 6. & Kunapa-Puya-Ama-Matsyagandhi & Sannipataja Atisara \\
\hline 7. & Mahat Putigandhi & Jalodara \\
\hline 8. & Nirgandha/Sagandha & Agantuja Atisara \\
\hline
\end{tabular}

Table 7: The Frequency/Abnormal Quantities of Purisa (Stool) in various diseases

\begin{tabular}{|c|c|c|}
\hline S. No. & Quantity/Frequency & Diseases \\
\hline 1. & Alpa & $\begin{array}{l}\text { Purisavaha Srotodushti, Pandu, Vataja Atisara, Sannipataj Jwara, Devon- } \\
\text { matta purusa }\end{array}$ \\
\hline 2. & Atipravritti/ Bahu & Pittaja Atisara, Amatisara, Asadhya Atisara \\
\hline 3. & Sanga & $\begin{array}{l}\text { Vataja Gulma, Apan vayu ruddha, Sushka Yoni, Udara roga, Vatasthila, } \\
\text { Mutra jathar, Baddhodara }\end{array}$ \\
\hline 4. & Alpa Alpa & Pravahika, Chidrodara, Vataja Grahani, Vataja Atisara, Kaphaja Atisara \\
\hline 5. & Muhur-muhu & Vataja Grahani, Vataja Atisara \\
\hline 6. & Bhedayukta & Kshayaja Yakshma, Sandharana janya Yakshma \\
\hline 7. & Kriccha & $\begin{array}{l}\text { Vataja Ashmari, Vidvighata, Amashaya kruddha vayu, Pakvashaya kruddha } \\
\text { vayu }\end{array}$ \\
\hline 8. & Sasabda & $\begin{array}{l}\text { Vataja Arsha, Amatisara, Purisvaha srotodushti, Puris kshaya, Vataja Gra- } \\
\text { hani }\end{array}$ \\
\hline
\end{tabular}


Table 8: Types of Shula (Pain) during defecation in various diseases

\begin{tabular}{|l|l|l|}
\hline S. No. & Types of Shula (Pain) & Diseases \\
\hline $\mathbf{1 .}$ & Sashula & Amatisara \\
\hline $\mathbf{2 .}$ & Sashula Sadaha & Pittaja Atisara \\
\hline $\mathbf{3 .}$ & Parikartika & Vataja Atisara \\
\hline $\mathbf{4 .}$ & Prahavana & Pravahika \\
\hline $\mathbf{5 .}$ & Shula, Gudstrava & Jalodara \\
\hline $\mathbf{6 .}$ & Chirat dukham & Vataja Grahani \\
\hline $\mathbf{7 .}$ & Sashula Pravahana & Kaphaja Atisara, Kaphaja Atisara, Pravahika \\
\hline $\mathbf{8 .}$ & Kunthan & Vishamagni, Samatisara \\
\hline
\end{tabular}

\section{Arista Laksanas (Bad Prognostic Signs)}

Purisa passed by a person which is ati-krsna (tarry black), ati-subhra (very white), ati-peeta (highly yellow), ati-rakta (highly red), chakrika yukta (containing shining plaques), ati-pramana (copious) even when no food is taken definitely kill the patient and patient dies quickly if associated with bhrsosma (excessive hotness). ${ }^{12,13}$

\section{Important Facts about Stool}

- The intestinal protozoan is usually found in the soft and liquid stool.

- Cysts are found in the formed stool and rarely found in liquid stool.

- Helminthes eggs are found in liquid or formed stool.

- Liquid stools are diluted, so difficult to finds parasites.

- Examined the surface of the unpreserved stool for macroscopic parasites.

- Pinworms are seen at the surface and tapeworms in the interior of the stool.

- The freshly passed stool is essential for the detection of amoebae or the flagellate.

- All liquid or soft stools should be examined within 30 minutes of the collection.

- Formed stool immediate examination is not critical, can wait for 3 to 4 hours.

\section{Reference Ranges of Normal Stool ${ }^{14}$}

- Bulk : 100-200 gms/day

- Color : Brown

- Water : Up to $75 \%$

- $\mathrm{pH} \quad: 7.0-7.5$

- $\mathrm{RBC} \quad$ : Absent
- WBC : Few

- Epithelial cells: Present

- Crystals : Calcium oxalate, triple phosphate

- Fat droplets : Average 2-5/HPF in random sample

- Urobilinogen: 50-300 mg/24 hours

- Parasites : Nil

- Ova, cysts, trophozoites: Nil

\section{DISCUSSION}

Purisa (Stool) is an important by-product of the metabolism and reflects the changes occurring in the body in different pathological, physiological and diseased conditions. Abnormal changes in purisa (stool) pertaining to its color, odor, consistency, frequency and quantity have been described in various disease conditions. An attempt has been made to collect these scattered references from Samhitas \& textbooks at one place and one can refer these changes in purisa (stool) for diagnosis of various disease conditions.

\section{CONCLUSION}

In all ancient days, the identification of ama is used to be done by purisa pariksha only. Malas or Kitta or Waste products of the body are of two kinds: Ahara mala and Dhatu mala. Ahara mala are the purisa and mutra while dhatu malas are many. Though these are malas, they sub serve for the maintenance of health so long as they are normal in their pramana (quantity), gunas (qualities) and karmas (functions). These malas also become abnormal (vriddhi and kshaya) conditions of the tridoshas. Purisa, which is one of the main metabolic products of the body, shows changes in its characters in diseased conditions. 


\section{REFERENCES}

1. Vaidya Laksmipati sastri, Yogaratnakara, Reprint, Varanasi, Vidyotini Hindi Commentary, Chaukhambha prakashan 2013, p. 5

2. Prof. K. R. Srikantha Murthy, Clinical Methods in Ayurveda, Varanasi, Chaukhambha orientalia, reprint 2013, p. 676

3. Dr. Sunil Verma, Sharira Kriya Vigyan, Varanasi, Chaukhambha orientalia, reprint 2013, p. 321

4. Pt. Kasinatha Sastri, The Caraka Samhita, Vidyotini Hindi Commentary, Sarirasthanam, chapter 7, verse 15, Varanasi, Chaukhambha Bharati Academy 2014, p. 915

5. P. B. Godkar, Textbook of Medical Laboratory Technology, Vol.-2, Mumbai, Bhalani Publishing House, $3^{\text {rd }}$ edition, 2016, p. 1504

6. Prof. K. R. Srikantha Murthy, Clinical Methods in Ayurveda, Varanasi, Chaukhambha orientalia, reprint 2013, p. 218

7. Uikey R, Kar AC. A review on Purisha Pariksha in Ayurveda. Ayu 2015;36:125-9.

8. Prof. K. R. Srikantha Murthy, Clinical Methods in Ayurveda, Varanasi, Chaukhambha orientalia, reprint 2013, p. 678

9. Pt. Kasinatha Sastri, The Caraka Samhita, Vidyotini Hindi Commentary, Chikitsasthanam, chapter 15, verse 94, Varanasi, Chaukhambha Bharati Academy 2014, p. 466

10. Kaviraja Ambikadutta Shastri, Susruta Samhita of Maharsi Susruta, Uttaratantra, chapter 40, verse 17-18, Varanasi, Chaukhamba Sanskrit Sansthan 2012, p. 278

11. Kaviraja Atrideva Gupta, Astanga Hrdayam of Vagbhata, Nidan sthanam, chapter 8, verse 14, Varanasi, Chaukhambha prakashan 2016, p. 338

12. Pt. Kasinatha Sastri, The Caraka Samhita, Vidyotini Hindi Commentary, Indriyasthanam, chapter 6, Varanasi, Chaukhambha Bharati Academy 2014, p. 993

13. Dr. P. S. Byadgi, Ayurvediya Vikrti Vijnana \& Roga Vijnana, Vol-1, Reprint, New Delhi, Chaukhambha Publications 2017, p.523

14. P. B. Godkar, Textbook of Medical Laboratory Technology, Vol.-2, Mumbai, Bhalani Publishing House, $3^{\text {rd }}$ edition, 2016, p. 1511

\section{Source of Support: Nil \\ Conflict of Interest: None Declared}

How to cite this URL: Ramnarayan Patel \& Aradhana Kande: A Conceptual Review On Purisa (Stool) Pariksha. International Ayurvedic Medical Journal \{online\} 2021 \{cited June, 2021\} Available from: http://www.iamj.in/posts/images/upload/1243_1248.pdf 